\title{
Managing goat production for meat quality
}

\author{
N.H. Casey*, E.C. Webb \\ Department of Animal and Wildlife Sciences, University of Pretoria, South Africa
}

\section{A R T I C L E I N F O}

\section{Article history:}

Available online $\mathrm{xxx}$

\section{Keywords:}

Goat

Meat quality

Genetic

Physiological

Genotype

Environment

\begin{abstract}
A B S T R A C T
Managing goat production for meat quality is a deliberate, active process that reaches from conception to consumption. The concept of quality in meat is universal, being wholesome, nutritious and palatable. Goat meat is a product of many different production systems from widely varying environments, nutritional regimes and genotypes. The physical, chemical, sensory and nutritional properties of goat meat at the point of consumption are the results of sequential influencing factors that each, to a greater or lesser extent, can be directed by producers, marketers and processors. This paper considers genetic and physiological factors that influence the production of goat meat.
\end{abstract}

(c) 2010 Elsevier B.V. All rights reserved.

\section{Introduction}

Goats, the earliest ruminant to be domesticated, are traditional sources of meat, milk, fibre, leather, related products of animal origin and as draught and pack animals. This long tradition of goats being a source of resources allowed them to become an integral part of culture as an indicator of wealth and symbolic roles in rituals. Goats are the most abundant of domesticated ruminant livestock. Their distribution across latitudes and the range of breeds with distinct morphological and physiological traits exceeds that of any other livestock (Galal, 2005).

The emergence of this bio-diversity among goats has been incidental rather than deliberate. It is the consequence of human migrations and where humans have settled, of local requirements for the animals to survive the rigours of the environment that could range from desert to tropical, or from lowland to highlands. In the process of adapting to the environment, goats expressed specific morphological and physiological traits that could be exploited by humans and be incorporated into their own endeavours

\footnotetext{
is This paper is part of the special issue entitled: Plenary papers of the 9th International Conference on Goats, Guest Edited by Jorge R. Kawas.

* Corresponding author.

E-mail address: norman.casey@up.ac.za (N.H. Casey).
}

to survive. Females were milked and the best producers kept and bred until the trait was expressed more prominently. Distinct breeds emerged that could be referred to as milk goats. Goats at high altitudes and harsh climates developed fibres, mohair and cashmere, that could be used. Goats in the tropics developed characteristically smaller bodies and smooth coats.

The common denominator has been meat, which has also been incidental to the prevalent production system. The traditional distinction between attributes for carcasses and meat quality has been age first and gender second. The available market for unprocessed, fresh goat meat has changed from being limited to local markets to global mega markets. Goat meat is exported from Africa, Australia and other regions to the states of the Arabian Gulf that have a burgeoning population, but have limited capacities to produce goat meat. In the global market, consumer quality and the guarantee of quality and supply are the criteria for a sustained market.

\section{Goat meat production}

In southern Africa (Namibia, South Africa, and Botswana), the south-western states of the USA and Mexico, meat production from goats is a commercial enterprise to many livestock farmers. The action is delib- 
erate. However, in other areas such as the western regions of Syria, goats are part of a mixed cropping-livestock system and multiple service providing milk, dairy products and meat for the family (Wurzinger et al., 2008). A similar situation prevails in Kenya (Bett et al., 2007a) and in southern Africa where indigenous goats are kept by small-scale farmers, communal farmers and households (Roets and Kirsten, 2005). Off-take as meat for sale in these systems is marginal. Although commercial meat goat farming is an established enterprise in southern Africa, a very small proportion $(<1 \%)$ of the total off-take of goats is slaughtered at centralised commercial abattoirs for distribution to city retail outlets (Coetzee, 1998). This is due to the nature of meat consumption where beef, sheep and poultry meat are preferred by the majority of urbanised households. The remainder of the goat meat is consumed by rural communities. Cultural preferences add to this disparity.

Efforts have been made to develop a more vibrant commercial goat meat industry by engaging the small-scale, household and communal farmers (Roets and Kirsten, 2005). In Kenya, smallholder production systems that utilize the Kenya Dual Purpose goat derived income from sales of milk, surplus yearlings and cull-for-age animals (Bett et al., 2007a). Meat accounted for $55 \%$ and milk $45 \%$ of the income in smallholder medium potential systems, and in smallholder high potential systems the contribution of meat declined to $40 \%$ and that of milk increased to $60 \%$. This illustrates the potential contribution of meat to household income in smallholder systems.

The constraints to goat production that require investigation and development, particularly in small-scale farming systems, noted by Van Marle-Köster et al. (2004), are genetic identification of local goat populations, evaluation of the available nutritional status and the improvement of small-scale farming systems. In addition, the development of a goat meat industry requires readily accessible infrastructure in the form of livestock marketing routes, facilities for slaughtering and processing carcasses and wholesale and retail distribution systems to a receptive and sustainable market.

\subsection{Defining goat meat quality}

The quality of fresh meat is a relative concept. Meat quality can be defined strictly in terms of its physical and chemical properties, or in terms of consumers' perceptions. Quality constituents, as noted by Webb et al. (2005), are being discovered and redefined continually.

Anatomical features and chemical components that contribute to the characteristic quality attributes of goat meat were reviewed by Webb et al. (2005) and Gigli and Saltalamacchia (2007). A general definition of meat quality is that of eating quality that comprises palatability, wholesomeness and being free of pathogens and toxins. Palatability includes tenderness, flavour, residue-free and succulence. Each of these criteria is dependent on other biological factors that include the animal's age and gender, and non-biological factors-pre-slaughter stress, slaughtering techniques and chilling and freezing of the carcass. The live animal's physiological state and the biochemistry of the post-mortem muscle, fat and connective tissue have direct influences on the palatability of meat. Feed influences meat quality through the accretion of muscle tissue, the ratio of muscle to fat, and the accretion of fat and the component fatty acids. Flavour is due to species-specific flavonoids in the meat from feed sources, the proportions of fatty acids in the various fat depots and the effect of genetics on the character of tissues and metabolism. The definition of meat quality is therefore multifaceted and intricate.

\subsection{Genetic development of goat breeds for meat production}

A production programme for goat meat would begin with the choice of breed that could be adapted to the climatic and topographic environment, or that is suitable for a particular production system. The breed must have the characteristics of a meat-producing animal. It must be robust for extensive rangeland conditions and be resistant or tolerant to endemic diseases, with high fertility and fecundity. Females must have excellent mothering abilities with sufficient milk for the number of suckling kids to grow to a heavy weaning weight. Weanlings must be strong and adapt well to foraging, with high post-weaning growth rates to a point of market readiness. Males must show prominent masculine features, have high pre- and post-weaning growth indices, display keen libido and be fertile. The goats must be responsive to and thrive on the available feed to deliver carcasses with adequate proportions of tissue composition and distribution for a given market (Sebsibe et al., 2007).

Development of the South African Boer Goat is an example (Casey and Van Niekerk, 1988; Van Niekerk and Casey, 1988; Campbell, 2003). The Boer goat was selected from indigenous goats by traditional hand-and-eye methods, and was developed through selective breeding. Since 1970 a national goat Performance Testing Scheme assesses:

- The dam's characteristics, her milk production and preweaning growth rate of her progeny.

- The post-weaning growth of progeny at various ages.

- The feed conversion efficiency and body weight of male progeny under standardized conditions.

- The post-weaning growth of male progeny under standardised conditions.

- The qualitative and quantitative carcass components of a sire's progeny.

Many farmers now opt to do the post-weaning growth assessment of male progeny under rangeland conditions with a cluster of progeny from each sire where the variables are individuals, sires, owners, year and season. The system of performance testing has shown its merit to select both male and female breeding stock and is applied by commercial producers. The concept should be encouraged among small-scale producers.

The SA Boer Goat, Savanna and Kalahari Red are the commercial goat breeds for meat production, while the Angora goat contributes substantially to the volume of goat meat mainly through the culling of male kids and redundant females. The informal rural sector farms mostly 
with Savannah goats that conform to the criteria of robustness for extensive rangeland conditions and resistance to endemic diseases, with high fertility and fecundity. A limitation for meat production is that the Savanna goats do not exhibit the further criteria for meat goats of high weaning weight and post-weaning growth rates and a high-value carcass due to either a lack of genetic potential, or the suppressed expression of genetic potential due to poor environmental conditions and health management, or the interaction between these factors. Savanna goats are typical of many village goats in tropical and sub-tropical regions that would have the potential to be developed into commercial meat breeds. The advantages and disadvantages of changing the character of a breed to a commercial meat breed need to be considered in each case.

\subsection{Genetic variances between populations}

The opportunity to conduct a selection programme for specific meat production and quality traits is dependent on the genetic variance within the population. A study of three commercial and three indigenous goat populations from South Africa for genetic variation using ten micro satellite markers showed heterozygosis values of between 0.62 and 0.69. The exception was the Boer Goat, which had the lowest variation of 0.49 . Genetic differentiation using fixation index (FST) values indicated a clear genetic differentiation between the Boer goat and the Kalahari Red population, 0.28 , while only moderate genetic differentiation was observed among the other populations (Visser et al., 2004). A more recent study showed the genetic variation within breeds as relatively high with heterozygosis values for Boer goats being 0.57, Kalahari Red, 0.68, and Savannah goats, 0.69 (Pieters and van Marle-Köster, 2007). The genetic distance between different populations within the Kalahari Red population was relatively small, ranging from 0.07 to 0.17 (Kotze et al., 2004).

Ecological regions give rise to goats with morphological features that enable them to be classed as breeds by the local people. The genetic differentiation between four different goat ecotypes in Namibia was found to be relatively low, 0.11 , which partly supports the phenotypic differences between these ecotypes. The four ecotypes seem to have evolved to suit their distinct environments and the heterozygosis values indicate sufficient genetic variation with the range being from 0.60 to 0.71 . The genetic distance between geographically close ecotypes was 0.12 and between two geographically distant breeds, the Kalahari Red that had evolved on the dry hot plains of the Northern Cape and the goat of the tropical Caprivi in the north of Namibia, was 0.44 (Els et al., 2004).

\subsection{Reproduction as a criterion for meat production}

Reproduction is the most important production parameter. The number of offspring born and the number that are weaned and survive to market readiness determine to a large extent the economic viability of the production system. Fertility is both a heritable trait and one that can be managed through nutrition and health management programmes. The heritability estimate of reproductive performance in ruminant livestock is generally low $\left(h^{2}=0.10\right)$. Goats are however highly fertile with a high fecundity where twinning is common. A characteristic meat genotype, the Boer goat has a high fertility index, while other reproduction parameters are also high.

The Boer Goat Association of South Africa advocates norms for commercial meat goat breeds: $90 \%$ kidding percentage, $210 \%$ fecundity, $165 \%$ weaning percentage and a $29 \mathrm{~kg}$ weaning weight at 120 days. Averages attained per 100 females through the PTS were $98 \%$ females kidded, and out of a total of 189 kids, $12.7 \%$ singles, $61.4 \%$ twins, $23.8 \%$ triplets and 2.1\% quadruplets (Campbell, 2003).

Reproductive performance is dependent on maternal, paternal and environmental factors. This dependency and the interactions can be described by $r_{\mathrm{p}}=[m][p][e]$, where $r_{\mathrm{p}}$ is the reproductive performance, $m$ (maternal effects) is the doe conception + age + kidding + milk production $+\ldots+[e]$, $p$ (paternal effects $)=$ fertility + libido $+\ldots+[e]$, and $e$ is a matrix of random environmental effects.

The reported results by Mandonnet et al. (2005) provide an interesting example of managing reproductive performance. A managed kidding period, especially in the tropics, since goats are poly-oestrous, can mean a shorter overall inter-kidding interval and the greater probability of obtaining three kiddings in a two-year cycle. The effect of kidding day was derived from an analysis of 5732 records of kids born in Guadeloupe. By using the male effect the goatherd had been subjected to a restricted mating season. Kidding day had a highly significant $(P<0.001)$ effect on growth rate and total productivity of females. The birth weights of kids born around Day 21 of the kidding period were 4-7\% higher than those of kids born on Day 1 of the kidding period. Day of kidding had no effect on litter size. The direct genetic effect was $h^{2}=0.25 \pm 0.05$, the genetic maternal effect was $0.09 \pm 0.04$ and the genetic correlation between direct and maternal effects was $-0.86 \pm 0.12$. The results demonstrated that the use of kidding day could be highly recommended in a breeding program in meat goats, as for this population of Creole meat goats, since it is quite easy to record under commercial conditions as a character related to reproductive performance.

Goats in the tropics have a less defined natural breeding season than those in the temperate regions. The indigenous goats of southern Africa tend to breed all year round (Greyling, 1988), though Webb and Mamabolo (2004) found that among smallholder farmers where little attention was given to a managed breeding season, the highest kidding rates among indigenous goats were attained in autumn (96\%), followed by spring (93\%), winter (63\%) and summer (0\%). The average kidding interval was 238 days. The key to attaining the results of Mandonnet et al. (2005) is an applied management of the breeding season, and the potential to achieving this is present also in indigenous goats in the tropics.

Litter size as noted above is an important trait for meat production. Todaro et al. (2004) found that litter size had no effect on carcass characteristics, though the meat of twins was significantly lighter in colour than that of singles. This is considered to be important because consumers of capretto meat prefer pale meat. Sex of the kids had no effect on meat colour. A sex effect was heavier males $(4.1 \mathrm{~kg})$ than 
females ( $3.9 \mathrm{~kg})$, but with no significant difference in chemical fat content of the hind limb. These results are to be expected given the androgenic effect in males that begin before birth and the low level of relative accretion rate of fat in both sexes at that early stage of growth and development.

A study of variance components, heritability (direct additive and maternal) and correlations (additive genetic, phenotypic, maternal genetic and environmental) of body weight (BW) and body size including length, height and chest girth at birth in Boer goats, showed that maternal effects were important determinants of the genetic parameters for birth traits. Medium and positive environmental correlations indicated the important effects of environmental factors on early growth traits, while the effects of year and season birth traits were significant (Zhang et al., 2008). The correlations between direct additive and maternal genetic effects were negative for all the birth traits. The estimates of additive genetic and phenotypic correlations among the birth traits were high and positive, and implied no genetic antagonisms among these traits analyzed. Estimates of maternal genetic correlations also were high and positive. Direct additive heritability estimates were: body weight, $0.19 \pm 0.08$; body length, $0.14 \pm 0.07$; body height, $0.24 \pm 0.09$; and girth, $0.25 \pm 0.10$.

Heritability estimates in SA Boer goats of pre-weaning growth traits suggest there is value in selecting for weaning weight or ADG. The analysis included birth weight, weaning weight, ADG and Kleiber ratio, with birth year, age of dam, sex and rearing status (a combination of birth and weaning status) as fixed effects. Heritability estimates obtained from different models, ranged from 0.16 to 0.33 for birth weight, 0.16 to 0.35 for weaning weight, 0.18 to 0.26 for ADG, and 0.13 to 0.23 for Kleiber ratio. Estimates from animal models that excluded maternal genetic effects were biased upwards, while the inclusion of maternal genetic effects resulted in lower and presumably more realistic variance components. Maternal effects were large for birth weight and small for the other three traits (Van Niekerk et al., 1996).

\subsection{Maturity types}

Goats, as with sheep, cattle and poultry, can be classified as early, medium or late maturing genotypes. Maturity types are differentiated in terms of carcass development and the degree of lean and fatness. The accretion of lean tissue (muscle) and fat are at different rates when measured in an allometric relationship $y=a x^{b}$ where $y$ is the weight of the component tissue, $x$ the reference against which the rate of growth of $y$ is determined (body weight) and $b$ is the exponential rate of change of $y$, designated the growth coefficient. The rate of accretion changes as the animals grow towards maturity. In early growth, the growth coefficient of lean tissue is $>1$ and decreases to $<1$ as the animal reaches maturity. Fat tissue has a very low rate of gain in young animals that increases to $>1$ as fattening proceeds (Casey, 1982; Casey and Naudé, 1984).

The derivative $\left(\mathrm{d} y / \mathrm{d} x=A b x^{b-1}\right)$ at any value $x$, or at any body weight, describes the instantaneous rate of change of tissue $y$ with respect to $x$ at that point $x$, being body weight. By equating the differentials of lean tissue (muscle) and fat tissue $\left(\mathrm{d} y_{\mathrm{m}} / \mathrm{d} x=\mathrm{d} y_{\mathrm{f}} / \mathrm{d} x\right)$, the body weight, $x$, at which the two tissues are growing at the same rate is established. At a body weight beyond this point, the rate of gain of fat tissue exceeds that of lean tissue. Under normal circumstances where nutrition is adequate for normal growth, this critical point is reached at a lower body weight in early maturing than in later maturing genotypes. Over the weight range of $10-41 \mathrm{~kg}$, male SA Mutton Merino, SA Merino, Dorper and Pedi (fat-tail breed) reached the critical point at body weights of 42.3, 27.8, 27.2 and $22.2 \mathrm{~kg}$, respectively, an indication that these breeds could be ranked from late to early maturing genotypes. By comparison, Boer goat males reached the critical point at a projected body weight of almost $50 \mathrm{~kg}$, illustrating that the Boer goat may have a muscle growth than the sheep breeds and hence the characteristic leanness of the goat carcass. Mahgoub and $\mathrm{Lu}$ (2004) corroborated the species differences of goats having significantly lower fat, but higher protein levels. In meat production, a long phase of accretion of lean tissue has the advantage of better feed conversion efficiency.

The same proportions of carcass composition (63\% muscle, $2 \%$ fat and $13 \%$ bone) were attained in a nonsignificantly differing time-span, 148-156 days from $10 \mathrm{~kg}$ liveweight, but at largely different body weights in the sheep breeds: SA Mutton Merino at $43 \mathrm{~kg}$, Dorper at $34 \mathrm{~kg}$ and Pedi at $24 \mathrm{~kg}$. This phenomenon is likely to occur among meat goat breeds of differing maturity types, for example, the Boer goat and the smaller Savannah goat of southern Africa. The determining factors will be environmental effects of sustained nutrition, heat or cold stress, disease and parasitic load.

The breed effect was illustrated in a study of eightmonth-old males from three Ethiopian goat breeds (Sebsibe et al., 2007). Growth and carcass characteristics of the Afar, Central Highland $(\mathrm{CH})$ and Long-eared Somali (LES) were evaluated using three grain-less diets varying in concentrate to roughage ratios under feedlot conditions. Diet I was 50:50 (8.5 MJ ME/kg DM), Diet 2 was 65:35 (9.2 MJ ME/kg DM) and Diet 3 was 80:20 (10.0 MJ ME/kg $\mathrm{DM}$ ), with a native grass hay as roughage and a concentrate consisting of wheat bran and noug cake (Guizotia abyssinica). Genotype affected the carcass characteristics significantly, and the internal fat depots. In all respects, the LES showed the characteristics of a late maturing genotype and the CHG the least physiologically mature. The LES carcass was more compact with a greater buttock circumference. The ADGs were LES $43.9 \pm 2.05 \mathrm{~g}, \mathrm{CHG} 34.7 \pm 2.09 \mathrm{~g}$ and the Afar $36.7 \pm 2.04 \mathrm{~g}(P=0.05)$. The LES had heavier slaughter and carcass weights, more fat and a thicker layer of subcutaneous fat than other breeds. The diets significantly affected ADG, but the effect was similar on carcass traits except for dressing percentage on an EBW basis and some non-carcass components. Diet 1 yielded the highest DP whereas the effect of breed was significant, in which the LES recorded the highest DP of 55.8\%. The partitioning of fat in the goat must be considered in the interpretation of these results. The goat has more internal fat and less on the carcass than sheep breeds. DP is the proportion of dressed carcass weight to liveweight that gives a higher DP in the leaner animal. 


\subsection{Carcass and meat quality attributes}

Carcass and meat quality are the selling points that should be guaranteed through grading or classification systems, or certified production systems. The European "Cabrito de Barroso PGI" and "Borrego Terrincho-PDO" specifications are designed to ensure the carcass composition and meat quality attributes of suckling male and female kids and lambs. Santos et al. (2008) compared the carcass and meat quality of Portuguese native goat and sheep breeds produced by these specifications. Suckling lambs had greater dressing percentage than suckling kids, while carcass fatness was not affected by species. Females had more kidney knob and pelvic fat than males. This difference between the sexes can be ascribed to the kidney knob and pelvic fat depots being early developing fat depots, whereas the no-difference in chemical fat content of the hind limb (Todaro et al., 2004) is due to this fat depot being late developing. The differences between species namely that lambs had greater proportions of the high-valued leg cut and lower proportions of shoulder, anterior rib, and neck cuts than kids and that kid carcasses had more muscle content and less dissected fat and bone than lambs, reflect the differences between species reported by Casey (1982) and Casey and Naudé (1984). Ultimate muscle $\mathrm{pH}$ was higher in kid than lamb carcasses ( $5.8 \pm 0.02$ vs. $5.6 \pm 0.02)$, and higher in male than in female carcasses $(5.7 \pm 0.02$ vs. $5.6 \pm 0.02)$. The kid meat was significantly lighter and less yellow than the lamb meat. Kids presented less cooking losses than lambs, and shear force value was significantly greater in lamb meat. The kid meat had significantly more moisture and less intramuscular fat content than lambs. At this maturity stage, there were significant differences on both carcass and meat quality attributes of suckling kids and lambs, possibly due to inherent differences between species.

The foregoing results indicate that a meat goat can be derived by deliberate selection for the characteristic traits. Multiple births and sex may have no significant effect on capretto. The effect of sex expresses itself only later when androgenic and oestrogenic hormones begin to determine physiological and morphological characteristics. Management of kidding day could increase the reproductive performance of females. Maturity types occur among meat goats, in a similar manner as among sheep breeds. The Boer and Long Eared Somali goats have the characteristics of late maturing genotypes, and as a small ruminant, the goat may be more efficient in muscle deposition to a target carcass composition than sheep breeds. It remains important that any development of a meat goat from local breeds must be done with circumspection, especially where goats have evolved to be adapted to distinct environments.

\section{Pre-slaughter management}

The environments in which meat goats are produced determine their productivity and the characteristics of the carcass and meat. Some genetic $x$ environment interactions have been noted above.
Pre-slaughter management practices can have an important economic impact on a goat meat enterprise. In many areas goats are slaughtered at very young ages as cabretto. In other regions the animals are slaughtered before they have cut their first permanent incisors. This entails a weaning period when the kids can be vulnerable to stress if the transition is not managed correctly. In South Africa, the kids are given access to supplementary creep feed during the weaning period, before being isolated from the dams.

\subsection{Nutrition}

Nutrition is the first determining factor for all aspects of production. The energy needs of the free-ranging goat were discussed by Lachica and Aguilera (2005). Nutritional influences on growth, carcass composition and meat characteristics have been well documented (Casey, 1982; Casey and Van Niekerk, 1985; Mahgoub and Lu, 2004; Webb et al., 2005; Sebsibe et al., 2007).

More recent work has examined the effect of limited nutrition that may occur due to variation in seasonal nutrient supply or during periods of drought. In a study of yearling Boer $\times$ Spanish goat wethers to assess effects of initial body condition and subsequent level of feed intake on body composition, it was reported that the energy concentration in tissue mobilized or accreted by yearling meat goats within certain body condition ranges, may not necessarily be the same and appears to be influenced by initial animal characteristics and subsequent feeding conditions (Ngwaa et al., 2007). The effect of feed restriction for 45 , 60 or 75 days of eight month old male native goats followed by normal nutrition to support $50 \mathrm{~g}$ per day weight gain, showed the kids capable of considerable compensatory growth without any deleterious effect on carcass composition or their compensatory growth responses. The expected loss of weight, general condition and fat occurred, while the proportion meat protein content increased. The re-alimentation was associated with a greater ADG and less internal fat (Dashtizadeh et al., 2008). The results are aligned to those reported by Sebsibe et al. (2007).

Greenwood et al. (2008) considered some pre-slaughter management practices that may influence carcass characteristics of and the economic return on young goats. Effects of sex, weaning three weeks before slaughter, continuous fasting and water deprivation for up to $72 \mathrm{~h}$, and initial liveweight and body condition score on LW and carcass characteristics were studied in young goats to sixteen weeks of age, with a live weight of $13.6 \pm 2.4 \mathrm{~kg}$. A $24 \mathrm{~h}$ fasting period caused a $7.5 \%$ loss in live weight. This increased to $10.8 \%$ by $48 \mathrm{~h}$. The loss was greater in weaned than nonweaned goats after $48 \mathrm{~h}$, the difference being $2.6 \%$. Fasting period, weaning status and deprivation of water reduced dressing percentage. The loss in live weight carried over to the hot carcass weight and the retail meat yield, demonstrated the need to minimise time off feed and water before slaughter from both a welfare and an economic perspective.

The question often arises as to whether nutrition or genetics would have the greater effect on the profitability of a production system. Investigating the economic returns of smallholder low, medium and high potential goat farm- 
ing systems in Kenya, Bett et al. (2007b) reported that the positive economic values for most traits under fixed flock-size and fixed feed resource scenarios indicates that a unit increase in genetic merit for the traits would have a positive effect on the profitability of the systems. This underscores the value of the two fundamentals for goat meat production, nutrition and genetic improvement individually and the interaction between the two. Nutrition as the greater variable holds the greater risk, while genetic improvement has less variability and less risk, but cannot achieve optimum expression without adequate nutrition. In combination these determine carcass and meat quality and hence profitability of the production system.

\subsection{Post-mortem glycolysis}

The rate and extent of post-mortem glycolysis and ultimate $\mathrm{pH}$ of the muscle are critical factors that determine meat quality. Webb et al. (2005) noted that high ultimate $\mathrm{pH}\left(\mathrm{pH}_{\mathrm{u}}\right)$ values for goat muscles are prevalent in literature suggesting that goats generally may be highly prone to stress. Peri-mortem concentrations of glycolytic metabolites in muscles (Kannan et al., 2003; Simela et al., 2004b) and in the blood (Kannan et al., 2002) verify this suggestion. Kannan et al. (2003) reported muscle glycogen content of 50 and $55 \mu \mathrm{mol} / \mathrm{g}$ for stressed and unstressed old Spanish castrates (24-30 months old), and 20 and $40 \mu \mathrm{mol} / \mathrm{g}$ for stressed and unstressed young Spanish castrates (6-12 months old), respectively. Simela et al. (2004b) found that in a goatherd of mixed sex and age, glycogen concentrations averaged $33 \mu \mathrm{mol} / \mathrm{g}$. In both studies, glycogen levels were $\leq 50 \mu \mathrm{mol} / \mathrm{g}$ the minimum concentration required for sufficient lactic acid production in order to attain a satisfactory $\mathrm{pH}_{\mathrm{u}}$. Consequently, $\mathrm{pH}_{\mathrm{u}}$ values were in the higher range for all animals, but more so for the young Spanish castrates and the South African indigenous goats.

Additionally, the fact that there are reports of goat meat with normal or close to normal $\mathrm{pH}_{\mathrm{u}}$ values, such as the feral goats of Hogg et al. (1989), the Boer x Angora of Dhanda et al. (1999) and the older castrates of Kannan et al. (2003), precludes the notion that high $\mathrm{pH}_{\mathrm{u}}$ is an intrinsic characteristic of the species. This is supported by the fact that lower $\mathrm{pH}_{\mathrm{u}}$ values are associated with tenderness that is related to properties such as longer sarcomeres after chilling, lower shear force values and better colourimetric values (Simela et al., 2004a). However, it is not clear why goats are so susceptible to pre-slaughter stress. A possibility is what Hopkins and Fogarty (1998) refer to as a "genotype effect on animal behaviour', which implies that the excitable nature of goats predisposes them to yielding high $\mathrm{pH}$ meat.

\subsection{Transportation}

Transporting livestock to an abattoir has been shown to be a highly stressful and exhausting period. Bruising is a constant threat that has an economic consequence when carcasses are discriminated against or, in the extreme, condemned.

The 24-h period of deprivation of feed and water that gave rise to the losses reported by Greenwood et al. (2008) would be a typical period for transporting the animals fol- lowed by waiting period at the abattoir. In many countries, the waiting period is obligatory to allow the animal to recover from the effects of transporting, principally the re-establishment of glycogen levels. The notion of transporting has many facets that affect the animal's physiology and consequently the carcass and meat quality. Transport on open vehicles in very hot circumstances can be highly stressful. A liveweight loss of $3.7-7 \%$ was recorded in goats transported for $2 \mathrm{~h}$ on an open vehicle at an ambient temperature of $37^{\circ} \mathrm{C}$ (Kadim et al., 2006). The stress endured by the goats was shown by higher plasma cortisol, adrenaline, nor-adrenaline, and dopamine concentrations than the non-transported control group. Transportation stress affect $\mathrm{pH}_{\mathrm{u}}$ and expressed juices, percentage cooking loss and shear force. Despite the increased shear force values, sarcomere lengths were lower. The colour parameters lightness $\left(L-^{*}\right)$, redness $\left(a^{*}\right)$ and yellowness $\left(b^{*}\right)$ were negatively affected. There was no significant breed effect between Batina, Dhofari and Jabal Akdhar goats and no breed $\mathrm{x}$ treatment interaction.

\section{Conclusion}

The production of goat meat and the quality of the carcass and the meat can be influenced by applying management procedures through genetic and physiological routes. The objective of producing a meat goat adapted to a specific production environment that delivers a desired carcass and meat quality requires an optimum management strategy that combines both genetic and physiological procedures. Through genetics, animals can be selected to suite the given environment, to be later or earlier maturing types and to improve maternal traits. The management of physiological responses through nutrition and by limiting stressful environments and situations favours optimum growth rates and ultimately improve the quality of the carcass and the meat.

\section{References}

Bett, R.C., Kosgey, I.S., Bebe, B.O., Kahi, A.K., 2007a. Breeding goals for the Kenya Dual Purpose goat. I. Model development and application to smallholder production systems. Trop. Anim. Health Prod. 39, 477-492.

Bett, R.C., Kosgey, I.S., Bebe, B.O., Kahi, A.K., 2007b. Breeding goals for the Kenya Dual Purpose goat. II. Estimation of economic values for production and functional traits. Trop. Anim. Health Prod. 39, 467-475.

Campbell, Q.P., 2003. The Origin and Description of Southern Africa's Indigenous Goats. SA-ANIM SCI 2003, vol. 4, pp.18-22. http://www.sasas.co.za/Popular/Popular.html.

Casey, N.H., 1982. Carcass and growth characteristics of four South African sheep breeds and the Boer goat. DSc (Agric.) Thesis. University of Pretoria.

Casey, N.H., Naudé, R.T., 1984. Differential growth profiles of muscle and fat. In: Proceedings of the 2nd World Congress on Cattle and Sheep Breeding, p. 639

Casey, N.H., Van Niekerk, W.A., 1985. Fatty acid composition of subcutaneous and kidney fat depots of Boer goats and the response to varying levels of maize meal. S. Afr. J. Anim. Sci. 15, 2:60.

Casey, N.H., Van Niekerk, W.A., 1988. The Boer Goat. I. Origin, adaptability, performance testing, reproduction and milk production. Small Rumin. Res. 1, 291-302.

Coetzee, R.J., 1998. Socio-economic aspects of sustainable goat production. Research and training strategies for goat production systems in South Africa. In: Webb, E.C., Cronjé, P.B., Donkin, E.F. (Eds.), Proceedings of a Workshop, 22-26 November, pp. 14-17. 
Dashtizadeh, M., Zamiri, M.J., Kamalzadeh, A., Kamali, A., 2008. Effect of feed restriction on compensatory growth response of young male goats. Iran. J. Vet. Res. 9, 109-120.

Dhanda, J.S., Taylor, D.G., McCosker, J.E., Murray, P.J., 1999. The influence of goat genotype on the production of Capretto and Chevon carcasses. 2. Meat quality. Meat Sci. 52, 363-367.

Els, J.F., Kotze, A., Swart, H., 2004. Genetic diversity of indigenous goats in Namibia using microsatelite markers: preliminary results. S. Afr. J. Anim. Sci. 34, 65-67.

Galal, S., 2005. Biodiversity in goats. Small Rumin. Res. 60, 75-81.

Gigli, S., Saltalamacchia, F., May 2007. Goat meat quality characteristics and affecting factors. In: Proceedings of the International Symposium, The Quality of Goat Products: Models and Tools for Evaluation and Promotion, CRA-ZOE, Bella, Italy, pp. 97-104.

Greenwood, P.L., Finn, J.A., May, T.J., Nicholls, P.J., 2008. Pre-slaughter management practices influence carcass characteristics of young goats. Aust. J. Exp. Agric. 48, 910-915.

Greyling, J.P.C., 1988. Certain aspects of reproductive physiology in the Boer goat doe. DSc Thesis. University of Stellenbosch, South Africa.

Hogg, B.W., Catcheside, L.M., Mercer, G.J.K., Duganzich, D.M., 1989. Meat yields and chemical composition of muscle in New Zealand goats. Proc. N. Zeal. Soc. Anim. Prod. 49, 155-157.

Hopkins, D.L., Fogarty, N.M., 1998. Diverse lamb genotypes. 2. Meat pH, colour and tenderness. Meat Sci. 49, 477-488.

Kadim, I.T., Mahgoub, O., Al-Kindi, A., Al-Marzooqi, W., Al-Saqri, N.M., 2006. Effects of transportation at high ambient temperatures on physiological responses, carcass and meat quality characteristics of three breeds of Omani goats. Meat Sci. 73, 626-634.

Kannan, G., Terrill, T.H., Kouakou, B., Gelaye, S., Amoah, E.A., 2002. Simulated preslaughter holding and isolation effects on stress responses and live weight shrinkage in meat goats. J. Anim. Sci. 80, 1771-1780.

Kannan, G., Kouakou, B., Terrill, T.H., Gelaye, S., 2003. Endocrine, blood metabolite, and meat quality changes in goats as influenced by shortterm, pre-slaughter stress. J. Anim. Sci. 81, 1499-1507.

Kotze, A., Swart, H., Grobler, J.P., Nemaangani, A., 2004. A genetic profile of the Kalahari Red goat breed from southern Africa. S. Afr. J. Anim. Sci. 34, 10-12.

Lachica, M., Aguilera, J.F., 2005. Energy needs of free-ranging goats. Small Rumin. Res. 60, 111-125.

Mahgoub, O., Lu, C.D., 2004. Influence of various levels of metabolisable energy on chemical composition of whole carcass and non-carcass portion of goats and sheep. S. Afr. J. Anim. Sci. 34, 81-84.

Mandonnet, N., Alexandre, G., Arquet, R., Navès, M., Menéndez-Buxader, A., 2005. Relevance of the variability of kidding day in Creole goats in Guadeloupe. Livest. Prod. Sci. 92, 241-247.

Ngwaa, A.T., Dawson, L.J., Puchalaa, R., Detweilera, G., Merkel, R.C., TovarLunaa, I., Sahlu, T., Ferrell, C.L., Goetsch, A.L., 2007. Effect of initial body condition of Boer $\times$ Spanish yearling goat wethers and level of nutrient intake on body composition. Small Rumin. Res. 73, 13-26.

Pieters, A., van Marle-Köster, E., 2007. Genetic characterization of commercial goat populations in South Africa. MSc (Agric.) Dissertation. University of Pretoria.

Roets, M., Kirsten, J.F., 2005. Commercialisation of goat production in South Africa. Small Rumin. Res. 60, 187-195.

Santos, V.A.C., Silva, S.R., Azevedo, J.M.T., 2008. Carcass composition and meat quality of equally mature kids and lambs. J. Anim. Sci. 86, 1943-1950.

Sebsibe, A., Casey, N.H., van Niekerkl, W.A., Tegegne, A., Coertze, R.J., 2007. Growth performance and carcass characteristics of three Ethiopian goat breeds fed grainless diets varying in concentrate to roughage ratios. S. Afr. J. Anim. Sci. 37, 221-232.

Simela, L., Webb, E.C., Frylinck, L., 2004a. Effect of sex, age, and preslaughter conditioning on $\mathrm{pH}$, temperature, tenderness properties and colour of indigenous South African goats. S. Afr. J. Anim. Sci. 34, 208-211.

Simela, L., Webb, E.C., Frylinck, L., 2004b. Post-mortem metabolic status, $\mathrm{pH}$ and temperature of chevon from South African indigenous goats slaughtered under commercial conditions. S. Afr. J. Anim. Sci. 34, 204-207.

Todaro, M., Corraob, A., Alicataa, M.L., Schinellib, R., Giacconea, P., Prioloc, A., 2004. Effects of litter size and sex on meat quality traits of kid meat. Small Rumin. Res. 54, 191-196.

Van Marle-Köster, E., Visser, C., Casey, N.H., 2004. Goats in South Africa: a significant role player? S. Afr. J. Anim. Sci. 34, 36-39.

Van Niekerk, W.A., Casey, N.H., 1988. The Boer Goat. II. Growth, nutrient requirements, carcass and meat quality. Small Rumin. Res. 1, 355368.

Van Niekerk, M.M., Schoeman, S.J., Botha, M., Casey, N.H., 1996. Heritability estimates for pre-weaning growth in the Adelaide Boer Goat flock. S. Afr. J. Anim. Sci. 26, 6-10.

Visser, C., Hefer, C.A., van Marle-Köster, E., Kotze, A., 2004. Genetic variation of three commercial and three indigenous goat populations in South Africa. S. Afr. J. Anim. Sci. 34, 24-27.

Webb, E.C., Mamabolo, M.J., 2004. Production and reproduction characteristics of South African indigenous goats in communal farming systems. S. Afr. J. Anim. Sci. 34, 236-239.

Webb, E.C., Casey, N.H., Simela, L., 2005. Goat meat quality. Small Rumin. Res. 60, 153-166.

Wurzinger, M., Iniguez, L., Zaklouta, M., Hilali, M., Solkner, J., 2008. The Syrian Jabali goat and its production system. J. Arid Environ. 72, 384391.

Zhang, C.Y., Yang, L.G., Shen, Z., 2008. Variance components and genetic parameters for weight and size at birth in the Boer goat. Livest. Sci. $115,73-79$. 